\title{
STRUCTURAL AND THERMAL ANALYSIS OF TURBO CHARGER BLADES
}

TIMUR CHOBAN KHIDIR, ABBAS MOHAMMED ISMAEL

\& AYAZ AYDIN ABDULJABBAR

Department of Mechanical Engineering, Kirkuk University, Iraq

\begin{abstract}
This paper presents the structural and thermal analysis of turbo charger blades. In this study an analyzed of blades are obtained, and the results of (Von Mises Stress \& Deformation) are discussed with supplying the same speed, pressure and temperature conditions. Comparing the two types of blade metals (Cast Stainless Steel and AISI 316 Annealed Stainless Steel), for bearing (316L Stainless Steel), and shaft bearing (Alloy Steel). After obtaining the results of the analysis, a best metal used in the design are chosen in order to withstand high speeds and high temperature and failure preventing. The vertical air pressure on turbine blades is $100 \mathrm{Kpa}$ and friction force between bearing and shaft is 275 Newton, and Speed turbocharger is 80.000 r.p.m. Solid works software used to analyze the models.

KEYWORDS: Turbocharger Blades, Analysis, Solid works, Cast Stainless Steel \& AISI 316 Annealed Stainless Steel
\end{abstract}

Received: Feb 23, 2019; Accepted: Mar 13, 2019; Published: May 28, 2019; Paper Id.: IJMPERDJUN2019125

\section{INTRODUCTION}

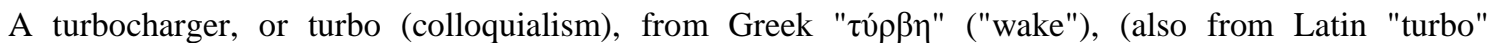
("spinning top"), is a gas compressor used to compress air to the internal combustion chamber to improve the output power from the engine [1]. This improvement over a naturally aspirated engine's output results so the turbine can force more air, and proportionately more fuel, into the combustion chamber than atmospheric pressure alone [2]. The first turbocharged passenger car was the Oldsmobile Jet fire option on the 1962-1963 F85/Cutlass, which used a turbocharger affixed to a $215 \mathrm{cu}$ in $(3.52 \mathrm{~L})$ all aluminum V8 [3]. Also in 1962, Chevrolet introduced a special run of turbocharged Corvairs, initially called the Monza Spyder (1962-1964) and later renamed the Corsa (1965-1966), which affixed a turbocharger to its air cooled flat six cylinder engine. This model popularized the turbocharger in North America-and set the stage for later turbocharged models from Porsche on the 1975-up 911/930, Saab on the 1978-1984 Saab 99 Turbo, and the very popular 1978-1987 Buick Regal/T Type/Grand National $[4,5]$. Today, turbo charging is common on both diesel and gasoline-powered cars [6]. Turbo charging can increase power output for a given capacity or increase fuel efficiency by allowing a smaller displacement engine [8]. Fiat 500 which selected as 2011 year engine, equipped with an MHI turbocharger. This engine lost $10 \%$ weight, saving up to $30 \%$ in fuel consumption while delivering the same HP (105) as a 1.4 liter engine [7]. The 2013 Chevrolet Cruze is available with either a 1.8 liter non-turbocharged engine or a 1.4 liter turbocharged engine-both produce the same 138 horsepower. Low pressure turbo charging is the optimum when driving in the city, whereas high pressure turbo charging is more for racing and driving on highways, motorways, and freeways [8].

In this research, a turbo charger designed done, the complete turbo charger, and then blades charged for comparing the analysis. After designing the apparatus in solidworks software program version 2016 we made a 
mesh for it so we can make the required analysis to compare the blades at the same conditions like speed, pressure and temperature and the other specifications are mentioned below.

Specifications of Turbocharger

Table 1: Physical Specifications of Turbocharger

\begin{tabular}{|l|l|c|c|c|}
\hline \multicolumn{1}{|c|}{ Description } & \multicolumn{1}{|c|}{ Material } & $\begin{array}{c}\text { Out Diameter } \\
\text { mm }\end{array}$ & $\begin{array}{c}\text { Inner Diameter } \\
\text { mm }\end{array}$ & Quantity \\
\hline Blades & $\begin{array}{l}\text { Cast Stainless Steel, and AISI } \\
\text { 316 Annealed Stainless Steel }\end{array}$ & 150 & 75 & 1 \\
\hline Bearing & 316L Stainless Steel & 30 & 12 & 2 \\
\hline Shaft & Alloy Steel & 12 & - & 1 \\
\hline Case of turbocharger & Alloy Steel & 230 & 80 & 1 \\
\hline
\end{tabular}

\section{METHODOLOGY}

Solidworks simulation is an analysis system fully integrated with solidworks. Which is provide simulation solutions for linear and nonlinear static, frequency, buckling, thermal, fatigue, pressure vessel, drop test, linear and nonlinear dynamic, and optimization analyses. Powered by fast and accurate solvers, it enables you to solve large problems intuitively while you design. It comes in two bundles: Solidworks Simulation professional and Solidworks Simulations Premium to satisfy your analysis need. Solidworks simulation shortens the time for optimum design [9].

\section{CAD-Models}

The solid model of bearing component is created in Solidworks V. 2016 software.
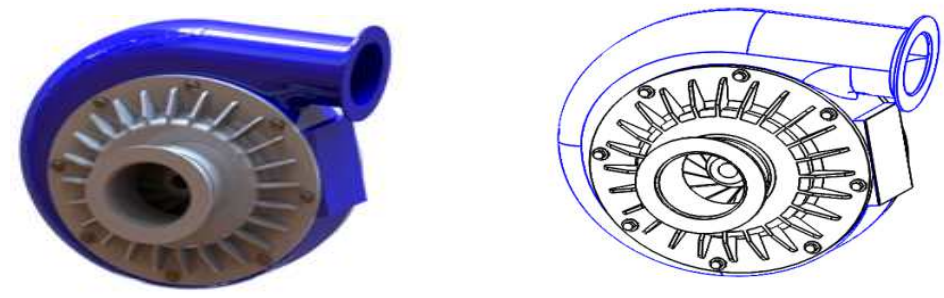

Figure 1: Isometric View of CAD Model of Turbocharger
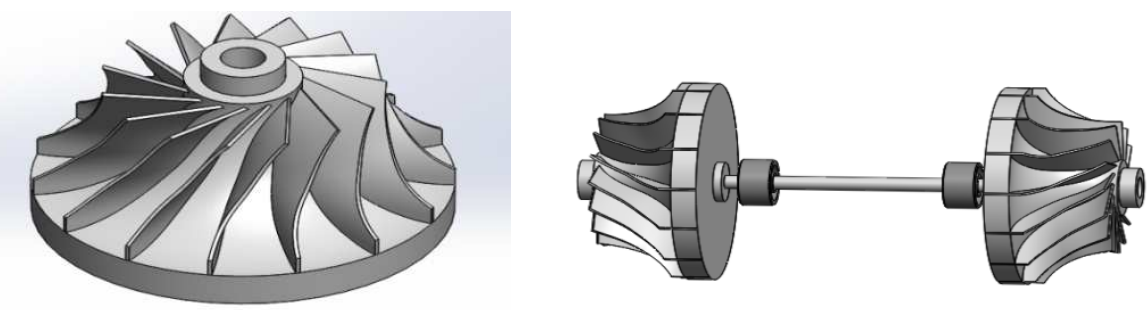

Figure 2: Isometric View of CAD Model Assembly of Blades, Bearing and Shaft

\section{Analytical Design of Turbocharger}

To design a turbocharger, we used two types of blades Cast Stainless Steel and AISI 316Annealed Stainless Steel and the value air pressure is $100 \mathrm{Kpa}$ and friction force on the bearing is $275 \mathrm{~N}$. The properties of both blades are mentioned in tables 2 and 3 . 
Table 2: Mechanical and Thermal Properties of Cast Stainless Steel

\begin{tabular}{|l|c|c|}
\hline \multicolumn{1}{|c|}{ Property } & Value & Units \\
\hline Elastic Modulus & 190000 & $\mathrm{~N} / \mathrm{mm}^{2}$ \\
\hline Poisson's Ratio & 0.26 & $\mathrm{~N} / \mathrm{A}$ \\
\hline Mass Density & 7700 & $\mathrm{~kg} / \mathrm{m}^{3}$ \\
\hline Thermal Conductivity & 37 & $\mathrm{~W} /(\mathrm{m} . \mathrm{K})$ \\
\hline Specific Heat & 520 & $\mathrm{~J} / \mathrm{kg} . \mathrm{K}$ \\
\hline
\end{tabular}

Table 3: Mechanical and Thermal Properties of AISI 316 Annealed Stainless Steel

\begin{tabular}{|l|c|c|}
\hline \multicolumn{1}{|c|}{ Property } & Value & Units \\
\hline Elastic Modulus & 192999.9974 & $\mathrm{~N} / \mathrm{mm}^{2}$ \\
\hline Poisson's Ratio & 0.3 & $\mathrm{~N} / \mathrm{A}$ \\
\hline Mass Density & 8000 & $\mathrm{~kg} / \mathrm{m}^{3}$ \\
\hline Thermal Conductivity & 16.3 & $\mathrm{~W} /(\mathrm{m} . \mathrm{K})$ \\
\hline Specific Heat & 500 & $\mathrm{~J} / \mathrm{kg} . \mathrm{K}$ \\
\hline
\end{tabular}

In this work, Solidwork simulation is used for a meshing of turbocharger. It creates sufficient meshing as shown in figures below.
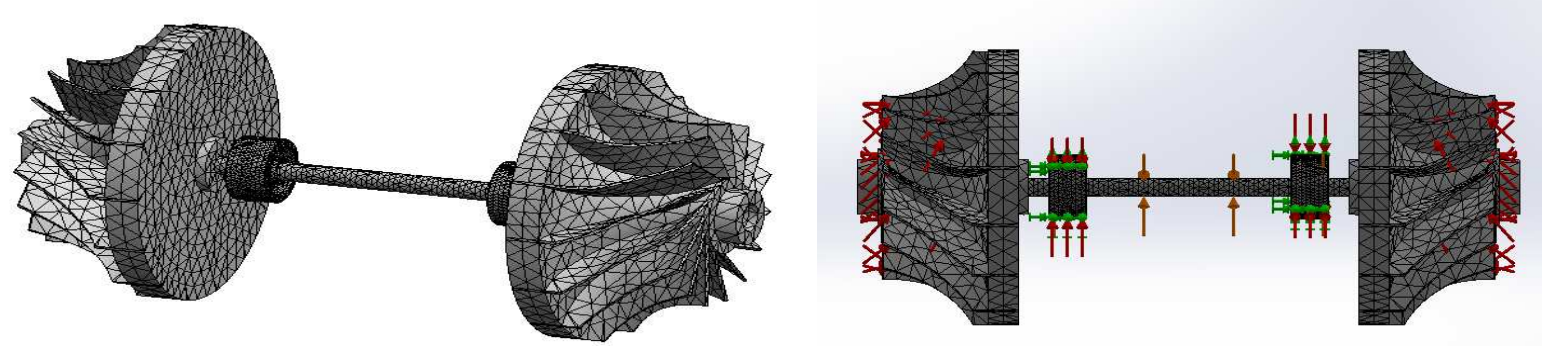

Figure 3: Meshing of Assembly of Blades, Bearing and Shaft

Analysis: Cast Stainless Steel for Blades

The simulation of blades, bearing and shaft (von mises stress and deformation) are analyzed.

1 - Von Mises Stress
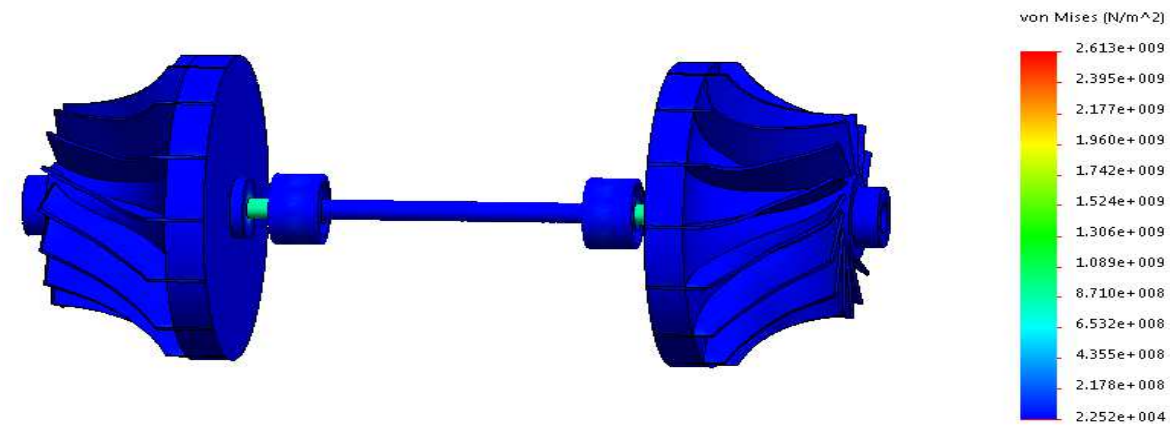

Figure 4: Simulation of Von Mises Stress Turbocharger 


\section{2- Deformation}

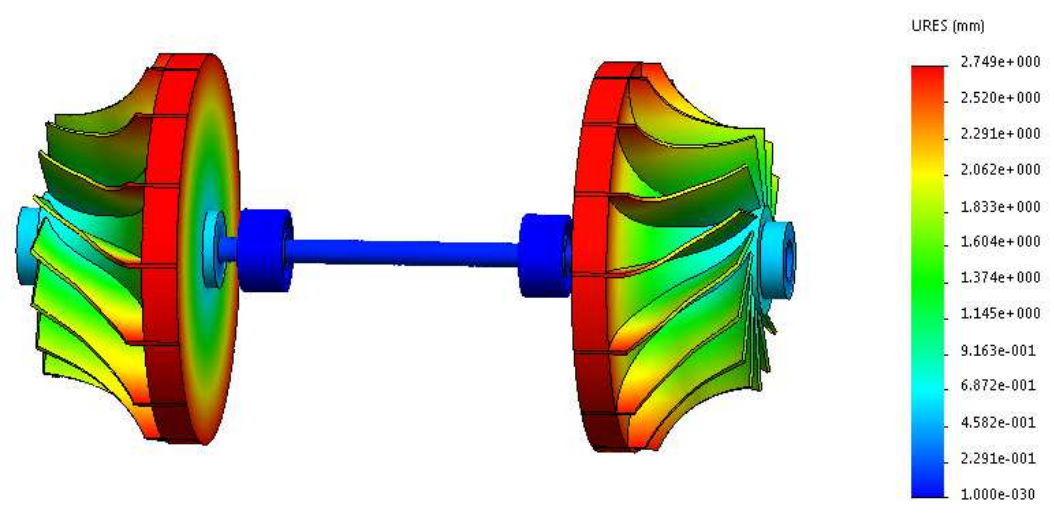

Figure 5: Simulation of Deformation Turbocharger

Analysis: for AISI 316 Annealed Stainless Steel Blades

The simulation of blades, bearing and shaft (von mises stress and deformation) are analyzed.

1 - Von Mises Stress

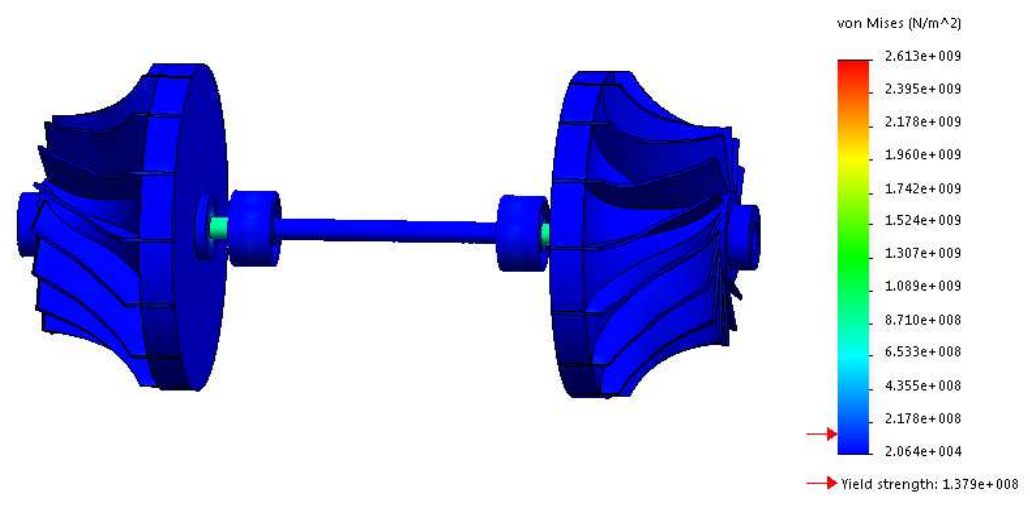

Figure 6: Simulation of von Mises Stress Turbocharger

\section{2- Deformation}

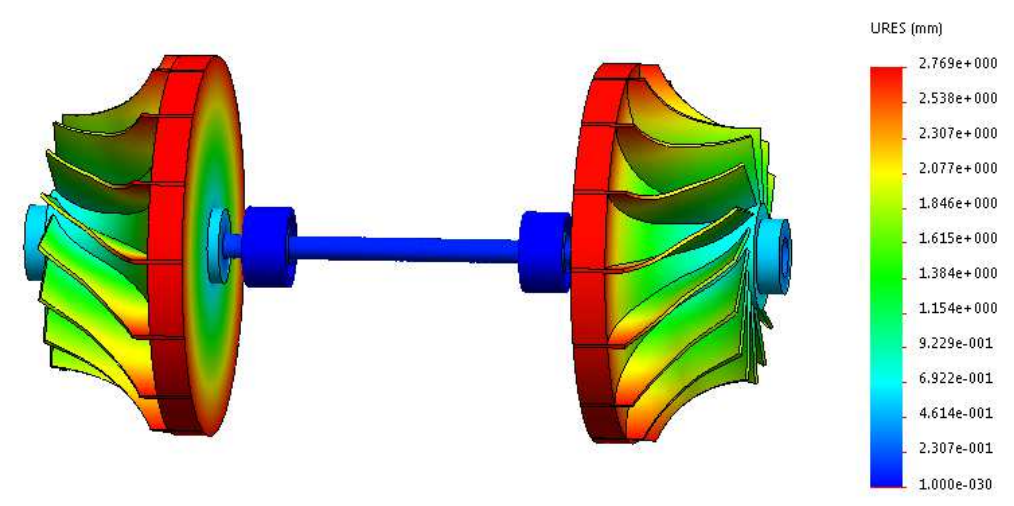

Figure 7: Simulation of Deformation Turbocharger 


\section{Thermal Analysis}

Table 4: Boundary Conditions

\begin{tabular}{|c|c|c|c|c|}
\hline Name of Material & $\begin{array}{l}\text { Temphot } \\
\text { Turbo }{ }^{\circ} \mathrm{C}\end{array}$ & $\begin{array}{l}\text { Temp Cold } \\
\text { Turbo }{ }^{\circ} \mathrm{C}\end{array}$ & $\begin{array}{c}\text { Ambient } \\
\text { Temperature }{ }^{\circ} \mathrm{C}\end{array}$ & $\begin{array}{c}\text { Convection } \\
\mathbf{W} /\left(\mathbf{m}^{2} . \mathbf{K}\right)\end{array}$ \\
\hline Cast Stainless Steel & 500 & 30 & 25 & 597 \\
\hline $\begin{array}{l}\text { AISI } 316 \text { Annealed } \\
\text { Stainless Steel }\end{array}$ & 500 & 30 & 25 & 597 \\
\hline
\end{tabular}

- Cast Stainless Steel: (thermal conductivity $=37 \mathrm{~W} /(\mathrm{m} . \mathrm{K})$, Specific Heat $=520 \mathrm{~J} / \mathrm{kg} . \mathrm{K})$, the temperature simulation done on the blades as shown in figure 8.

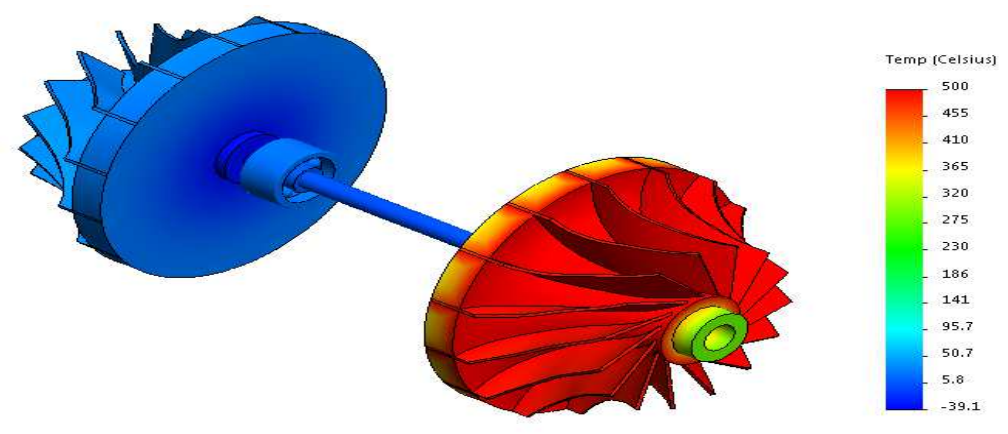

Figure 8: Temperature Simulation for Cast Stainless Steel

- AISI 316 Annealed Stainless Steel: thermal conductivity= $16.3 \mathrm{~W} /(\mathrm{m} . \mathrm{K})$ and Specific Heat= $500 \mathrm{~J} /(\mathrm{kg} . \mathrm{K})$, figure 9 shows the temperature simulation on AISI 316 Annealed Stainless Steel blades.

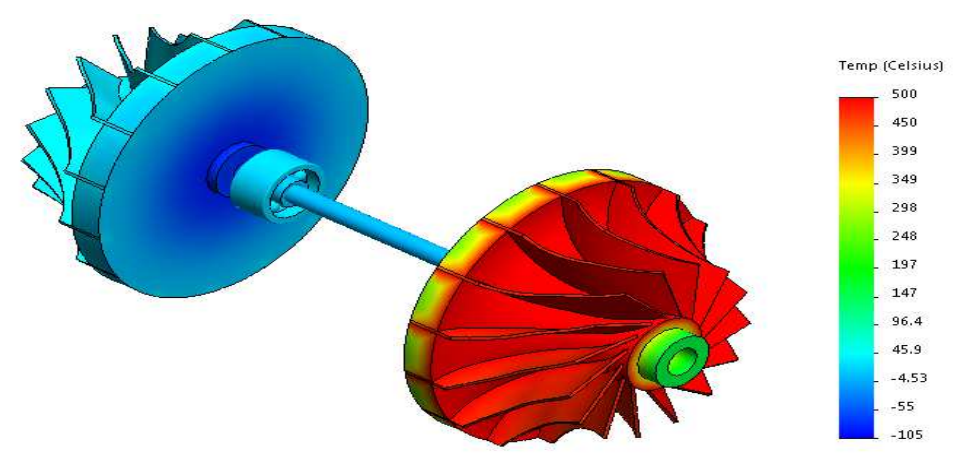

Figure 9: Temperature Simulation for AISI 316 Annealed Stainless Steel

The temperature increasing with time is compared between the cast stainless steel and AISI 316 annealed steel as shown in figure 10 . 


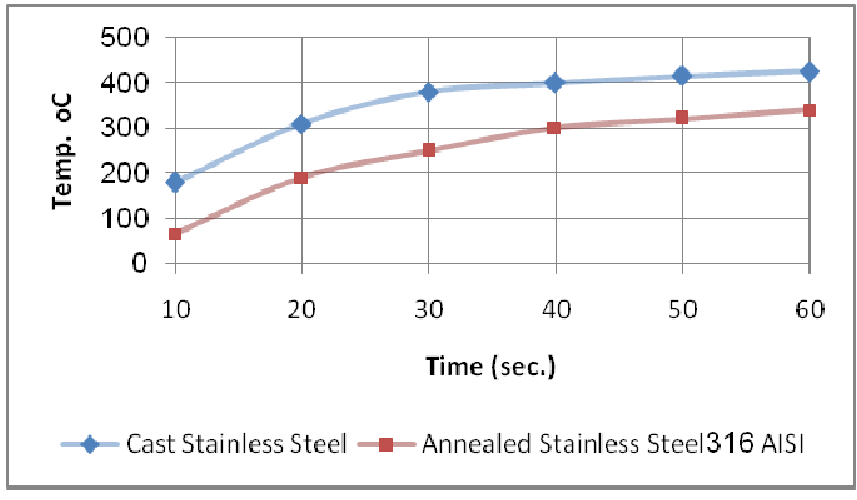

Figure 10: Temperature Variation with Time

\section{RESULTS AND DISCUSSIONS}

Firstly, the structural analyses for two types of turbocharger blades have done. First one is Cast Stainless Steel and the other is AISI 316 Annealed Stainless Steel. After checking and comparing the obtained results of Von Mises Stress at the same boundary conditions we found that the two types of turbocharger blades are close as shown in Figures 4, 6, while the maximum deformation in metals for Cast Stainless Steel is $2.749 \mathrm{~mm}$ and for AISI 316 Annealed Stainless Steel is $2.769 \mathrm{~mm}$ as shown in Figures 5 and 7. Through this analysis, it's appeared that both metals have almost close robustness. Secondly, the thermal analyses for these two types of turbocharger blades have done too. The examination effect of changing the metal type of turbocharger blades are shown in Figures 8 and 9, while the temperature increasing by time as shown in figure 10 occurred that the temperature at the surface of turbocharger blades for Cast Stainless Steel between (410-455) $\mathrm{C}^{\circ}$, while in the case of metal AISI 316 Annealed Stainless Steel, the temperatures are between (298-349) $\mathrm{C}^{\circ}$ at the same boundary conditions. This means that the metal AISI 316 Annealed Stainless Steel surface metal has a heat loss of more than Cast Stainless Steel which means that the AISI 316 Annealed Stainless Steel is suitable for designing blades.

\section{REFERENCES}

1 Watson, N. and Janota, M. S., 1982, Turbo charging the Internal Combustion Engine.

2 Wiley, New York. Gunter, E. G. and Chen, W. J., 2005,Dynamic Analysis of a Turbocharger in Floating Bushing Bearings, Proc. 3rd International Symposium on Stability Control of Rotating Machinery, Cleveland, $\mathrm{OH}$.

3 Gunter, E. G. and Chen, W. J., 2000, Dy RoBeS - Dynamics of Rotor Bearing Systems User's Manual, RODYN Vibration Analysis, Inc., Charlottesville, VA.

4 Holmes, R., Brennan, M. J. and Gottr and, B., 2004,Vibration of an Automotive Turbocharger, Proc. 8th International Conference on Vibrations in Rotating Machinery, Swansea, UK, pp 445- 450.

5. Patel, B., \& Subhedar, D. (2016). Experimental and Numerical Investigation of Diesel Engine Turbocharger. International Journal of Automobile Engineering Research and Development (IJAuERD) ISSN (P), 2277-4785.

6 Kirk, R. G., 1980, Stability and Damped Critical Speeds: How to Calculate and Interpret the Results, Compressed Air and Gas Institute Technical Digest, 12(2), pp. 1-14.

7 Alsaeed, A. A., 2005, Dynamic Stability Evaluation of an Automotive Turbocharger Rotor-Bearing System, M.S. Thesis, Virginia Tech Libraries, Blacksburg, VA.

8 Static and Thermal Analysis of Turbine Blade of Turbocharger Kamlesh Bachkar, W.S. Rathod M.Tech Student, Assistant Professor Department of Mechanical Engineering, Veermata Jijabai Technological Institute, Mumbai, Maharashtra, India. 
9 Turbocharger blade vibration: Measurement and validation through laser tip-timing J.M.Allport, M.L.Jupp Cummins Turbo Technologies, UK A.Pezouvanis, G.W.Janicki, A.I.Pierończyk, A.J.Day, P.Olley, B.Mason and M.K.Ebrahimi School of Engineering, Design and Technology, University of Bradford, UK.

10. Dinesh, S., Antony, A. G., Rajaguru, K., \& Parameswaran, P. (2018). Comprehensive analysis of wire electric discharge machining process in machining high chromium high carbon steel. International Journal of Mechanical and Production Engineering Research and Development (IJMPERD), 8(1), 65-74.

11. Solidworks Engineering Design and Technology Series, 2016.

\section{AUTHOR DETAILS}

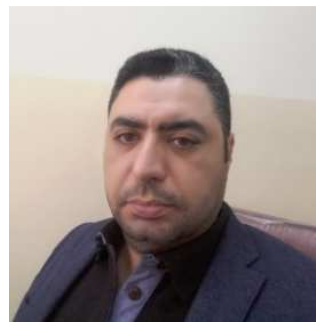

\section{Timur Choban Khidir}

B.Sc. University of Technology-Baghdad / Mech. Eng. - 2005

MsD. Gazi University (Ankara) / Turkey - 2010

Specialist: Applied mechanic

Lecturer in College of Engineering / Kirkuk University 
